\section{Division of Japanese psychiatry}

SIR-As the visiting scientist who drew the attention of Nature to the events surrounding the seventh congress of the Japanese Society of Biological Psychiatry in April 1985 (see Nature 315, 361; 1985), I was interested to read the contribution of Dr K Moriyama (Nature 318,$308 ; 1985)$ to the debate. As I understood the situation (from psychiatrists attending the meeting in Nagoya), it was indeed threats from the group with which $\mathrm{Dr}$ Moriyama is associated that led to the abandonment of the seventh congress, a satellite symposium on schizophrenia to be held in Gifu and then the ad hoc meeting organized in a hotel in Nagoya.

Two issues have emerged. Undoubtedly there are aspects of the Japanese mental health care system that are at variance with practice in other advanced nations. The report of the factfinding mission of the International Commission of Jurists and International Commission of Health Professionals (see Nature 316, 571; 1985) highlights a number of problems. One would expect that these would be the subject of discussion within and outside the psychiatric community in Japan and that someone of $\mathrm{Dr}$ Moriyama's declared interests would be working within a professional and political context (for example through a body such as MIND) for legal changes.

The second issue relates to freedom of exchange of scientific information. Dr Moriyama writes of "protest action taken against the seventh congress". Undoubtedly he and his followers have created a situation in which organizers feel obliged to cancel meetings rather than face confrontation. I understood from the psychiatrists to whom I spoke at the aborted meeting in Nagoya that previous "protest action" had ended in physical violence with the possibility of serious injury to meeting participants. A visitor to Japan has difficulty in understanding how Dr Moriyama and his colleagues justify adopting tactics that presumably are illegal, and finds it equally perplexing that the congress organizers did not consider the protection of the law adequate to allow the congress to continue.

Dr Moriyama alleges that the papers to be presented at the seventh congress reveal "evidence of many unethical experiments". I have a copy of the volume of 114 numbered abstracts that were to have been presented. These are mostly in Japanese, although the sections that are not indicate that the topics include many that were discussed at the recent World Congress of Biological Psychiatry in Philadelphia. I invite $\mathrm{Dr}$ Moriyama to indicate which abstracts he considers raise particular ethical issues. I will then arrange for these abstracts to be translated and submitted to a United Kingdom ethical committee (see for example Denham et al. "Work of a district ethical committee', Br. Med. J. ii, 1042-1045; 1979) or to a comparable American institutional review board. It will then be possible to assess whether there is independent support for the views expressed by Dr Moriyama.

Clinical Research Centre,

Division of Psychiatry,

Harrow, Middlesex HAl $3 U J, U K$

\section{Animal intelligence}

SiR-I should like to add to J.H. Fremlim's letter on animal intelligence (Nature 316,$760 ; 1985$ ). Human intelligence is not only quantitatively but also qualitatively different from animal intelligence because it recognizes time as a dimension. Man knows that there is a future in addition to the past and the present.

The awareness that a future exists gives man the incentive to plan, and to ensure that the plan succeeds. He therefore prepares weapons for the hunt and containers for the foraging expedition. This culminates in the discovery of agriculture, in the knowledge that seed planted in the spring will bring in a rich harvest in the fall, enabling him to survive the winter in comfort.

1104 Windon Drive,

Wilmington, Delaware 19803, USA

\section{Aleksandrov}

SIR-Vera Rich writes (Nature 318, 592; 1985) of "rumours circulating in the West" that Academician Vladimir Aleksandrov, who disappeared in Madrid last April, had been intending to defect, but was prevented by Soviet security men.

We no longer live in a time when every member of a Soviet delegation abroad is shadowed by another. Vladimir Aleksandrov, like many of his compatriots travelling in the West, had countless opportunities to defect. At a conference in Helsinki in $1984 \mathrm{I}$ met him early one morning jogging in some woods - with nobody on his heels. And Western embassies in many capitals would surely be glad to give asylum to a leading Soviet mathematician and computer scientist.

It is also simply speculaticn to suppose that Soviet official silence on Academician Aleksandrov's disappearance indicates sinister goings-on. It is not Soviet policy to utter publicly on events that are
Watford Road. bad news, unless it is to prevent their recurrence. Of course these rumours may be right, but where is the evidence?

Stewart Britten

9d Stanhope Road,

London N6 5NE, UK

\section{Creationism}

SIR-In his Commentary on the unreasonable claims of scientific creationists, Michael Cavanaugh (Nature 315, 185; 1985 ) seems to ignore the boundaries in biology that separate some observations from their causes and which are the basis for appealing to history, whether traditional or conjectured. Scientists have deciphered the genetic code, but chemical genetics has not supplied a theory for its origin. The stability of nuclear DNA has frustrated understanding how and from where organisms might acquire the enormous amount of genetic information needed to leap the persisting gaps in the fossil record - and on so grand a scale to bring whole populations into existence suddenly and worldwide. Cosmologists, too, recognize that the equations of the big bang theory are not capable of describing conditions before the big bang.

To assert in the absence of scientific theory that the origin of the genetic code and acquisition of new genetic information by organisms nevertheless occurred spontaneously is clearly a matter of faith. Evolutionists and creationists are therefore epistemological equals who are free to choose which history provides more meaning for life.

Creationists are indebted to evolutionists for having put the history of Genesis 1 to the test. Practice of the scientific method has established boundary conditions concerning origins that are evidence for a creator. Along with evolutionists, creationists predict that these boundaries one day will open to rational thought.

Box 543, Loma Linda,

D.H. Koobs

\section{California 92354, USA}

\section{Is anyone there?}

SIR - There must surely be something magical about the "magic frequencies" at which, you report (Nature 317, 275; 1985), yet another project is searching for extraterrestrial signals. But the magic is that anyone should waste their time, and our money, searching the bands where interference and attenuation of any such signals is at a maximum.

Any rational ET communication engineer would transmit at frequencies where these are at a minimum. Is anyone looking in the right place?

\section{M.H. Macdonald}

8 Wilton Street,

Brighouse, Yorkshire, UK 